Section Editors

David C. Spencer, MD

Steven Karceski, MD

Laura A. Kalayjian, MD

\title{
Valproate and pregnancy
}

\author{
Think again
}

In their article "IQ at 6 years after in utero exposure to antiepileptic drugs: A controlled cohort study," Dr. Baker and colleagues ${ }^{1}$ studied the long-term cognitive effects in children whose mothers took antiseizure medications while pregnant. They studied 243 pregnant women with epilepsy and 287 pregnant women without epilepsy (also known as "controls") for comparison. They performed IQ testing on both groups of children at age 6 . They chose this age because it is a good predictor of thinking and learning later in life. Children of women with epilepsy were grouped based on which antiepileptic medications they were exposed to in utero.

WHAT WERE THE MAIN FINDINGS? Children exposed to high-dose valproate $(>800 \mathrm{mg} /$ day $)$ had lower IQ (by almost 10 points) than control children. They were also 8 times more likely than control children to need extra help at school. Children exposed to low-dose valproate $(<800 \mathrm{mg} /$ day $)$ did not have lower IQ but were 6 times more likely to need extra educational help than controls. The IQs of children exposed to other common seizure medications-carbamazepine or lamotrigine-did not differ from control children. They were not more likely to need help at school. Some previous studies have shown that taking a vitamin supplement called folic acid during pregnancy helps to avoid learning problems in children exposed to antiseizure medications in utero. This study did not find that to be true.

WHAT SETS THESE FINDINGS APART FROM EARLIER WORK? This is the largest study of its kind. By following these children from the very beginning (or "prospectively"), researchers can more precisely determine what factors affect learning and cognition.

WHY ARE THESE FINDINGS IMPORTANT? This information adds to the growing data that taking valproate during pregnancy is risky. Valproate use in pregnancy increases birth defect rates. It also affects a child's learning ability. ${ }^{2}$ It may increase chances of autism spectrum disorder or other behavioral issues. The US Food and Drug Administration has already issued a warning on this topic. It states that women of childbearing age should not take valproate due to its potential effect on an unborn child's IQ unless no other medication can keep the patient safe.

Most women with epilepsy are not able to stop taking medications when they find out they are pregnant. It has been known for a long time that antiseizure medications can cause birth defects. Now we also know that some can create learning problems that do not show up until years after the baby is born, even though no birth defect is seen. This creates a risk that pregnant women with epilepsy might stop taking medication out of fear. This can lead to larger problems, as grand mal seizures can hurt both mother and unborn child. Patients need better information about how specific antiseizure medications affect the developing brain of an unborn child so they can make informed choices with the support of their doctors. Ideally these decisions are made long before pregnancy in order to avoid future problems.

WHAT IS THE NEXT STEP? We do not know enough about the long-term effects of the other newer antiseizure medications on learning and behavior, although studies are going on now.

\section{REFERENCES}

1. Baker GA, Bromley RL, Briggs $\mathrm{M}$, et al; Liverpool and Manchester Neurodevelopment Group. IQ at 6 years after in utero exposure to antiepileptic drugs: a controlled cohort study. Neurology 2015;84:382-390.

2. Meador KJ, Baker GA, Browning N, et al; NEAD Study Group. Fetal antiepileptic drug exposure and cognitive outcomes at age 6 years (NEAD study): a prospective observational study. Lancet Neurol 2013;12:244-252. 


\section{PATIENT PAGE}

Section Editors

David C. Spencer, MD

Steven Karceski, MD

Laura A. Kalayjian, MD

\section{About pregnancy and epilepsy}

Epilepsy is a very common neurologic disorder. It affects many women during their childbearing years. About $50 \%$ of pregnancies in the United States are unplanned, but not unwanted. A woman with epilepsy must be prepared and plan for her future pregnancy to ensure the best possible outcome for her and her baby.

Since valproate can lower a child's IQ if taken by the mother during pregnancy, the US Food and Drug Administration recommends that it not be taken by women of childbearing age unless there is no alternative option. Many antiseizure medications carry some risk of birth defects, even some of the newer ones. Taking folic acid $1 \mathrm{mg}$ a day before becoming pregnant and during the pregnancy can reduce the chance of having a baby with a birth defect. It may also lessen the chance of learning problems due to antiseizure medication exposure in utero. Women who want to have a baby or who are sexually active but not using any type of birth control should consult their doctor. Forms of birth control include condoms, intrauterine devices, birth control pills, or birth control implants (e.g., Implanon, Depo-Provera).

Before a pregnancy is planned, the responsible physician may want to change the seizure medication or consider reducing or stopping it. If seizures were well-controlled for the 9 months prior to pregnancy, then seizures will most likely remain well-controlled during pregnancy. Up to one-third of patients can have worsening of their seizures during pregnancy. This can be due to changes in the way the body handles the antiseizure medications, increased hormones in the body, poor sleep, or not taking the medication properly. Levels of several antiseizure medications, including lamotrigine and levetiracetam, are known to decrease during pregnancy. Increases in dose are usually needed to maintain steady levels and seizure control.

Women with epilepsy can have regular vaginal births, but there are slightly increased rates of cesarean section delivery. Pregnant women may need to take vitamin $\mathrm{K}$ before delivery to help prevent bleeding. Breastfeeding benefits to the child must be weighed against the additional exposure of the baby to antiseizure medications in the mother's milk. At least one study showed that breastfeeding while taking antiseizure medication is safe and does not lower a child's IQ.

Mothers with epilepsy should practice good safety measures and never bathe the baby alone or have the baby in standing water. A baby can drown in a small amount of water if the mother is confused after a seizure.

Babies born to women taking antiseizure medications are at risk for birth defects. These are obvious signs that the baby did not develop normally in utero. These may include cleft lip or palate, spina bifida, or heart defect. Some signs of abnormal development can be harder to see. If the brain did not form properly, learning problems and behavioral problems may be the only sign. These will not be obvious when the baby is born but will show up later during preschool and elementary school. Women who took antiseizure medication while pregnant should let the baby's pediatrician know and have the baby checked for development problems. Most school districts will test children as young as 2 or 3 years old, and early intervention programs and Head Start programs can be initiated.

\section{FOR MORE INFORMATION}

Neurology Now $^{\circledR}$

http://journals.lww.com/neurologynow/Pages/Resource-

Central.aspx

Epilepsy Foundation

http://www.epilepsy.com/information/women/epilepsyand-pregnancy

Antiepileptic Drug Pregnancy Registry

http://www.aedpregnancyregistry.org/ 


\title{
Neurology
}

\author{
Valproate and pregnancy: Think again \\ Laura A. Kalayjian \\ Neurology 2015;84;e25-e26 \\ DOI 10.1212/WNL.0000000000001299
}

This information is current as of January 26, 2015

\section{Updated Information \& Services}

References

Subspecialty Collections

Permissions \& Licensing

Reprints including high resolution figures, can be found at: http://n.neurology.org/content/84/4/e25.full

This article cites 2 articles, 0 of which you can access for free at: http://n.neurology.org/content/84/4/e25.full\#ref-list-1

This article, along with others on similar topics, appears in the following collection(s):

All Epilepsy/Seizures

http://n.neurology.org/cgi/collection/all_epilepsy_seizures Antiepileptic drugs

http://n.neurology.org/cgi/collection/antiepileptic_drugs

Information about reproducing this article in parts (figures,tables) or in its entirety can be found online at:

http://www.neurology.org/about/about_the_journal\#permissions

Information about ordering reprints can be found online:

http://n.neurology.org/subscribers/advertise

Neurology ${ }^{\circledR}$ is the official journal of the American Academy of Neurology. Published continuously since 1951, it is now a weekly with 48 issues per year. Copyright (C 2015 American Academy of Neurology. All rights reserved. Print ISSN: 0028-3878. Online ISSN: 1526-632X.

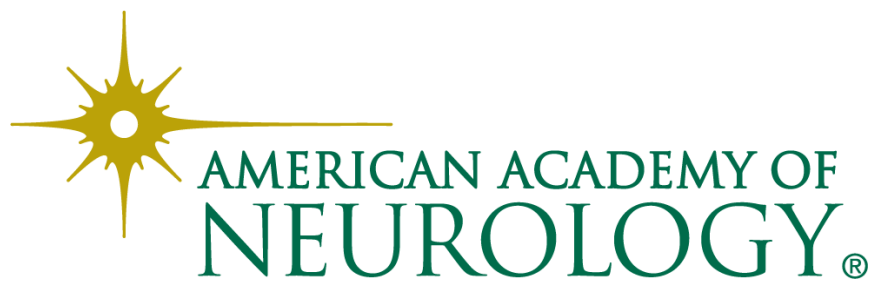

